\title{
DPF regeneration with high sulfur fuel
}

\begin{abstract}
During the first decade of Diesel particle filter development and deployment in cars, trucks, buses and underground sites, DPF regeneration methods were engineered to be compatible with the then prevalent high sulfur content in the fuel $>2000$ ppm. The mainly used methods were burners, electrical heaters, replaceable filters and non-precious metal fuel additives. Low sulfur Diesel fuel became only available from 1996 in Sweden, 1998 in Switzerland, and after 2000 everywhere in Europe. Thus, the deployment of precious metal catalytic converters was feasible both as original equipment and retrofitting of in-use engines. The so-called CRT particle filters using PGM-catalysis for providing $\mathrm{NO}_{2}$ for low temperature regeneration became very successful wherever ULSD was available. However, in many applications, e.g. off-road and in the construction industry, Diesel engines continued to run on high sulfur fuel and in many emerging countries, even on-road Diesel fuel still contains between 1000 and 2000 ppm sulfur. These countries suffer very much from air pollution through increasing Diesel particle emissions and the high impact of black carbon particles on human health as well as on the global warming is worrying. Hence, the necessity for modern particle filters which are compatible with high sulfur content of the fuel. In the context of Chinese megalopolis, this paper reports investigation of a fuel which is typical for China (containing $>1000$ ppm sulfur) and compares results with European standard Diesel fuel. The test objects were two modern SiC particle filters, which were regenerated using different iron-based FBC. The combustion attributes of the soot were investigated by TGA and their EC/OC composition was examined. The results indicate that at the given test conditions the fuel sulfur does not significantly change the filters' physical and chemical properties. Neither the filter particle loading process nor the filter regeneration is noticeably different for the high sulfur test fuel compared to the ultra-low sulfur European fuel. Therefore VERT-verified iron-based FBC-type DPF can be used in countries where ULSD is not yet available.
\end{abstract}

Key words: diesel particulate filter regeneration, high sulfur fuel

\section{Regeneracja filtra DPF dla paliw o dużej zawartości siarki}

W pierwszym dziesięcioleciu istnienia filtrów czastek statych w silnikach o zapłonie samoczynnym samochodów osobowych, ciężarowych i innych pojazdów, regeneracja filtra była realizowana przy uwzględnieniu zawartości siarki w paliwie powyżej 2000 ppm. Główne metody regeneracji polegały na wypalaniu, elektrycznym podgrzewaniu, wymianie filtrów $i$ dodawaniu do paliwa metali nieszlachetnych. Olej napędowy o małej zawartości siarki byt dostępny w Szwecji od 1996 roku, w Szwajcarii od 1998 roku, a od roku 2000 w całej Europie. Zastosowanie metali szlachetnych jako katalizatorów było możliwe zarówno przy oryginalnym wyposażeniu, jak i przy filtrze wymiennym dla eksploatowanych silników. Filtry CRT do niskotemperaturowej regeneracji, wykorzystujace $N_{2}$, (dostarczany za pomoca katalizatorów PGM) były dobrym rozwiązaniem dla wszystkich zastosowań ULSD. Jednak w wielu zastosowaniach silników o zaptonie samoczynnym, np. pozadrogowych, nadal stosowane jest paliwo o dużej zawartości siarki. Również w wielu krajach rozwijajacych się do zastosowań drogowych wykorzystywane jest paliwo o zawartości siarki 1000-2000 ppm. Niepokojace jest, że w krajach tych występuje duże zanieczyszczenie powietrza wynikające ze zwiększenia emisji czastek stałych z silników o zapłonie samoczynnym, co źle wptywa na zdrowie ludzi oraz zwiększenie efektu cieplarnianego. Wynika stąd konieczność stosowania filtrów cząstek stałych, które będą dobrze działały w sytuacji stosowania paliwa charakteryzującego się duża zawartościa siarki. W artykule zmieszczono wyniki badań dotyczace oleju napędowego wykorzystywanego w Chinach, o zawartości siarki powyżej 1000 ppm i porównano je z wynikami uzyskanymi dla standardowego paliwa stosowanego w Europie. Badania wykonano na dwóch nowoczesnych filtrach cząstek statych typu SiC, których regeneracja była przeprowadzona przy użyciu różnych FBC bazujących na żelazie. Parametry spalania sadzy badano metoda TGA i określono jej sktad EC oraz OC. Uzyskane wyniki wskazuja, że w pewnych warunkach zawartość siarki w paliwie nie wpływa na właściwości chemiczne i fizyczne filtrów cząstek stałych. Zauważono, że proces gromadzenia czastek $w$ filtrze oraz proces regeneracji różnia się w zależności od zawartości siarki w paliwie.

Słowa kluczowe: regeneracja filtra cząstek stałych, paliwo o dużej zawartości siarki

\section{Introduction}

Before 1990, HDV Diesel fuel in most countries contained 2000 ppm sulfur. DPF compatible with high sulfur content fuel were developed beginning 1980. These developments were documented at the annual SAE Sessions

\section{Wprowadzenie}

Przed rokiem 1990 olej napędowy stosowany do silników pojazdów HDV w większości krajów miał zawartość siarki 2000 ppm. Filtr cząstek stałych dla silników zasilanych takim paliwem został opracowany na początku lat 
on "Diesel Particulate Emission Control" [1] from 1982 onwards. Wall flow DPFs of this development period time were already very effective. The DPF deployment however, was limited to the retrofitting of in-use engines of public transport buses, subsequently construction machines and at underground sites. New engines proved to be able to fulfill the legal PM mass-based emission limits of this period without a DPF and for this reason the DPF did not become yet a standard element of the OEM engine emission control technology at this time.

Low-sulfur fuels first became available from 1996 in Sweden. The main reason was the environmental impact on the Swedish lakes and forests due to $\mathrm{SO}_{2}$ emission and sulfate formation, the so-called acid-rain formation. In other European countries and Switzerland the sulfur content fell stepwise from $2000 \mathrm{ppm}$ to $500 \mathrm{ppm}$, to $350 \mathrm{ppm}$, to $50 \mathrm{ppm}$ and then in 2002 to $10 \mathrm{ppm}$.

This was the result of the Auto Oil Programs 1 and 2, mainly driven by two arguments: first, that the sulfur in the fuel was the major factor influencing particle formation. However, this holds only true when the overall particle mass PM is collected at low temperatures, irrespective of particle size and substance and also capturing the sulfate condensate plus bound water [2]. The solid content in this particle mass $\mathrm{PM}$, consisting of insoluble ultrafine carcinogenic particles is independent of sulfur. The sulfate mass on the other side plus the bound water indeed constitute the volatile phase. The Worldwide Fuel Charter [4] confirmed that fact. Today including condensates in the PM-measurement is regarded to be a measuring artefact, resulting in far too low filter efficiencies [3] and misleading the emission technology development. This distinction between high toxic solid and low toxic volatile however, was only recognized later and reflected in the European Directive EURO 6 [5] after the PMP instrumentation was implemented.

The second strong argument, which finally was decisive, was that high sulfur content in the fuel impeded the performance of precious metal catalysts. Low sulfur fuel cleared the way after 2000. It also triggered the introduction of $\mathrm{NO}_{2}$ regenerating particle filter concepts like the Johnson Matthey CRT system and the Engelhard DPX system. The DPF retrofit market using these systems steadily grew, especially for public transportation. The inherent drawback of this concept was increased $\mathrm{NO}_{2}$-emission which was underestimated and contributing to today's high $\mathrm{NO}_{2}$ levels in street canyons having intense traffics [6]. Other filter systems using burner regeneration, base metal catalysis and fuel borne catalysts FBC were less successful because of higher complexity, lower performance or higher cost.

ULSD fuel also permitted the use of Diesel oxidation catalytic converters. Pt-based DOC became a standard component in European LD Diesel engines, permitting EGR for $\mathrm{NO}_{x}$ curtailment while diminishing $\mathrm{CO}$ and $\mathrm{HC}$. Here, too, the increasing $\mathrm{NO}_{2}$ emission was not limited. Grouping the oxides of nitrogen $\mathrm{NO}, \mathrm{NO}_{2}$ and $\mathrm{N}_{2} \mathrm{O}$ which are very different with respect to their physics and chemistry as well as to toxic effects to human, non-weighed into a single osiemdziesiątych minionego wieku. Rozwój tych filtrów był prezentowany w 1982 roku na corocznie organizowanej przez SAE sesji "Diesel Particulate Emission Control" [1]. Zastosowanie filtrów cząstek było ograniczone głównie do eksploatowanych autobusów komunikacji miejskiej, maszyn budowlanych i maszyn pracujących pod ziemią. W tamtym czasie nowe silniki spełniały limity emisji cząstek stałych bez konieczności zastosowania filtrów cząstek stałych, dlatego nie stały się one standardowym wyposażeniem nowo produkowanych silników.

Paliwo o małej zawartości siarki po raz pierwszy było dostępne w Szwecji w 1996 roku. Głównym powodem zmniejszenia zawartości siarki było negatywne oddziaływanie dwutlenku siarki na przyrodę oraz występowanie tzw. kwaśnych deszczy. W krajach Unii Europejskiej oraz Szwajcarii zawartości siarki zmniejszano stopniowo od 2000 ppm do 500 ppm, 350 ppm, 50 ppm, a następnie w 2002 r. do 10 ppm. Był to efekt programów Auto Oil 1 i 2 wprowadzonych głównie $\mathrm{z}$ dwóch powodów. Pierwszy dotyczył wpływu siarki na emisję cząstek stałych. Jednak ten powód jest zasadny tylko wtedy, gdy cząstki stałe są gromadzone w niskiej temperaturze, bez uwzględnienia ich wielkości i składu oraz skondensowanych siarczanów i wody [2]. Zawartość frakcji stałej w cząstce stałej składa się z małych nierozpuszczalnych oraz rakotwórczych cząstek i nie zawiera siarki. Siarczany i woda stanowia fazę lotną. Fakt ten jest potwierdzony w Światowej Karcie Paliw [4]. Obecnie uwzględnienie kondensatów w cząstce stałej podczas pomiarów jest uważane za błąd pomiaru, wynikający z właściwości filtrów [3] i wpływa niekorzystnie na rozwój metod pomiarów emisji. Rozróżnienie między dużą toksycznością frakcji stałej a małą frakcji lotnej uznano później, co znalazło odzwierciedlenie w dyrektywie Euro 6, w której został wprowadzony PMP [5].

Drugi powód, który był decydujący, to negatywne oddziaływanie siarki na metale szlachetne stosowane jako katalizatory. Paliwo o małej zawartości siarki stosowano od 2000 roku. To umożliwiło wprowadzenie regeneracji filtra z wykorzystaniem $\mathrm{NO}_{2}$. Na przykład wykorzystywane to było przez filtry CRT firmy Johnson Matthey i system DPX firmy Engelhard. Rynek wymiany filtrów rozwijał się szczególnie dla pojazdów komunikacji publicznej. Wadą tej metody jest zwiększenie emisji $\mathrm{NO}_{2}$, a to przyczynia się do zwiększenia stężenia tego związku, głównie w obszarach miejskich o dużym natężeniu ruchu [6]. Systemy regeneracji filtrów przez wypalanie, opierające się na katalizatorach metali szlachetnych FBC, nie stały się powszechne ze względu na duży stopień skomplikowania, wysokie koszty i małą sprawność.

Zastosowanie paliwa ULSD umożliwia także wykorzystanie utleniających reaktorów katalitycznych. Reaktory z katalizatorami z grupy platynowców stały się standardowym wyposażeniem silników o zapłonie samoczynnym pojazdów kategorii LD. Pozwoliło to na zastosowanie EGR-u w celu zmniejszenia $\mathrm{NO}_{x}$, przy jednoczesnym zmniejszeniu emisji $\mathrm{CO}$ i HC. Klasyfikowanie tlenków azotu na $\mathrm{NO}, \mathrm{NO}_{2}$ i $\mathrm{N}_{2} \mathrm{O}$, które różnią się właściwościami fizycznymi i chemicznymi 
"NO "-emission standard has blinded authority observance of emitted levels of $\mathrm{NO}_{2}$ - in contrast to occupational health where this grouping was never accepted and consequently Pt-based DOC were banned in some countries from being used in mines.

The influence of the fuel sulfur on the Pt-based catalysts is well documented [7]. With the presence of sulfur and oxygen the catalytic converter favors the conversion of $\mathrm{SO}_{2}$ $\rightarrow \mathrm{SO}_{3}$. This tenaciously inhibits other oxidation reactions, especially the reaction $\mathrm{NO} \rightarrow \mathrm{NO}_{2}$, so that the CRT reaction finally ceases at low exhaust-gas temperatures. On the other hand, when ULSD is used the reaction $\mathrm{NO} \rightarrow \mathrm{NO}_{2}$ is favored.

Introduction of low sulfur fuel however, remained limited. Many developing and emerging countries still use fuels with $>1000 \mathrm{ppm} \mathrm{S}$. Even most modern industrialized countries use this high-S cheaper fuel for construction machines, non-road and stationary engines, and locomotives. Fuels in ocean shipping have even higher S concentrations up to $4 \%$. Hence, emission control has been delayed in these sectors.

Nevertheless in most countries, the off-road sector contributes as much to PM as the on-road sector, because off-road emission regulation has lagged behind on-road. Consequently, the use of particle filters would be much more cost effective for off-road application.

Particle filter technology for high polluting off-road engines, burning high sulfur fuels, was therefore studied to define best available retrofit-technology for these applications. Target areas of immediate interest are underground workplaces worldwide and construction machines in France, UK, Italy, China and other countries.

As a result of these considerations all systems using precious metal catalysts and catalytic combustion had to be excluded from these high sulfur fuel applications. Burner systems, base metal coatings and fuel borne catalysts were selected as promising candidates. This study started with the investigation of two FBC systems, both based on iron.

\section{Test engine, lubrication oil and test setup}

Table 1 summarizes the data of the test engine and Fig 1 shows the measuring set-up.

This construction engine has been repeatedly investigated during the VERT project. Several SAE papers report prior investigations on this engine $[8,9]$. All its attributes are well known and documented. In this study, the usual exhaust-gas instrumentation was enhanced with nanoparticle analysis. This comprises a SMPS system with subsequent CPC. The sampling is PMP compliant [10], i.e. the exhaust-gas sample is heated to $300{ }^{\circ} \mathrm{C}$ and diluted approx. 1:100. Hence, only solid particles are counted.

Table 1 summarizes the data of the test engine and Fig. 1 shows the measuring set-up.

\section{Tested fuels}

The original Chinese fuel could not be exported from China to the Swiss engine lab. Hence the Chinese fuel was analyzed (1223 ppm S) and Shell formulated a similar fuel, which was used in the tests reported here (1369 ppm S). oraz toksycznym oddziaływaniem na zdrowie człowieka, nie jest rozróżniane $\mathrm{w}$ pomiarach $\mathrm{NO}_{\mathrm{x}}$. Normy emisyjne nie wyróżniają emisji $\mathrm{NO}_{2}$, w przeciwieństwie do norm medycyny pracy, w których reaktory DOC z katalizatorami $\mathrm{z}$ grupy platynowców zostały zabronione.

Wpływ siarki na katalizatory z grupy platynowców jest dobrze opisany w publikacji [7]. W obecności siarki i tlenu reaktor katalityczny sprzyja konwersji $\mathrm{SO}_{2} \rightarrow \mathrm{SO}_{3}$. Wpływa to korzystnie na ograniczenie utleniania innych związków, szczególnie $\mathrm{NO} \rightarrow \mathrm{NO}_{2}$. W związku z tym reakcje w układzie CRT zanikają przy niskiej temperaturze spalin. W sytuacji zastosowania paliwa ULSD reakcje utleniania $\mathrm{NO} \rightarrow \mathrm{NO}_{2}$ zachodzą z większą intensywnością.

Stosowanie paliwa o małej zawartości siarki nadal jest ograniczone w niektórych krajach rozwijających się, w których nadal stosowany jest olej napędowy o zawartości siarki powyżej 1000 ppm. Również w niektórych krajach wysoko rozwiniętych stosuje się paliwo o dużej zawartości siarki jako tańsze rozwiązanie, np. do silników maszyn budowlanych i innych zastosowań pozadrogowych. W transporcie morskim stosuje się paliwa o zawartości siarki nawet powyżej 4\%, co wpływa na opóźnienie działań zmierzających do kontroli emisji w tym sektorze $\mathrm{w}$ porównaniu $\mathrm{z}$ innymi środkami transportu.

W większości krajów pojazdy o zastosowaniach pozadrogowych znacząco przyczyniają się do zwiększenia emisji cząstek stałych. Wynika to głównie z tego, że limity emisji dla tych pojazdów są bardziej liberalne. Dlatego wtedy w celu poprawy wskaźników ekologicznych jest zasadne stosowanie filtrów.

Jednym z elementów modernizacji silników pojazdów o zastosowaniach pozadrogowych zasilanych paliwem o dużej zawartości siarki jest zastosowanie filtrów obniżających zawartość cząstek stałych - dla tych pojazdów emisja tego związku jest znaczna. Filtry cząstek stałych jako części wymienne znalazły zastosowanie w odniesieniu do maszyn pracujących pod ziemią oraz maszyn budowlanych w takich krajach, jak: Francja, Wielka Brytania, Włochy, Chiny i inne.

W wyniku przeprowadzonej analizy można stwierdzić, że nie powinno się stosować rozwiązań opartych na katalizie z wykorzystaniem metali szlachetnych w przypadku paliwa zawierającego duże ilości siarki. Jako obiecujące rozwiązanie wybrano system wypalania opierający się na reaktorze katalitycznym z warstwą metali. W artykule przedstawiono rozważania na temat dwóch systemów FBC bazujących na żelazie.

\section{Silnik i stanowisko badawcze}

Podstawowe dane techniczne badanego silnika spalinowego zamieszczono w tabeli 1, a na rysunku 1 przedstawiono schemat stanowiska badawczego. Silnik użyty do badań był już wielokrotnie badany w ramach projektu VERT, co opisano w kilku artykułach SAE [8,9]. Aparatura wykorzystana w pomiarach została wzbogacona o urządzenia umożliwiające analizę nanocząstek. W badaniach wykorzystano system SMPS oraz CPC. Pobór próbek spalin był zgodny z PMP [10], czyli próbka spalin była podgrzana do temperatury $300{ }^{\circ} \mathrm{C}$ 
Table 1. Test engine Liebherr D934 S

Tabela 1. Dane silnika Liebherr D934 S

\begin{tabular}{|l|c|}
\hline Manufacturer/producent & Liebherr \\
\hline Type/typ & D934S \\
\hline $\begin{array}{l}\text { Cylinder volume/objętość } \\
\text { skokowa }\end{array}$ & $6.36 \mathrm{dm}^{3}$ \\
\hline $\begin{array}{l}\text { Rated speed/maks. prędkość } \\
\text { obrotowa }\end{array}$ & $2000 \mathrm{rpm} /$ obr/min \\
\hline Rated power/maks. moc & $105 \mathrm{~kW}$ \\
\hline Max. torque/maks. moment & $680 \mathrm{Nm}$ \\
\hline $\begin{array}{l}\text { Model/liczba i układ cylin- } \\
\text { drów }\end{array}$ & 4 cylinder in-line/rzędowy \\
\hline $\begin{array}{l}\text { Combustion process/rodzaj } \\
\text { wtrysku paliwa }\end{array}$ & $\begin{array}{c}\text { Direct injection/bezpośredni } \\
\text { do komory spalania }\end{array}$ \\
\hline $\begin{array}{l}\text { Injection pump/pompa } \\
\text { wtryskowa }\end{array}$ & Bosch unit pump \\
\hline Supercharging/doładowanie & TC / IC/turbodoladowanie \\
\hline Emission control/norma emisji & none \\
\hline Design year/rok produkcji & 2005 \\
\hline $\begin{array}{l}\text { Application/zastosowanie } \\
\text { Construction machines/ } \\
\text { maszyny budowlane }\end{array}$ \\
\hline
\end{tabular}

The comparison shows that the Chinese Diesel fuel is very similar to the European, except for the sulfur content, and is not contaminated with more organic or inorganic components.

\section{Tested particle filtres}

Both tested filter systems are VERT certified [11]. The most important data are collected in Table 2.

\section{Analytical methods}

\subsection{Granularity analysis}

The size classification of the solid soot particles was determined using the SMPS procedure (Scanning Mobility Particle Sizer) [12]. The particle classification and particle counting was done after heating the gas sample to a tempera-

Table 2. Tested particle filter systems

Tabela 2. Badane filtry cząstek statych

\begin{tabular}{|c|c|c|c|}
\hline Manufacturer/producent & & Dinex A/S & $\begin{array}{l}\text { Pirelli Eco Technology } \\
\text { S.p.A. }\end{array}$ \\
\hline Material/materiat & & $\mathrm{SiC}$ & $\mathrm{SiC}$ \\
\hline Porosity/porowatość & {$[\%]$} & 45 & 42 \\
\hline Pore size/wielkość por & {$[\mu \mathrm{m}]$} & 15 & 20 \\
\hline Cell number/liczba cel & [CPSI] & 150 & 180 \\
\hline $\begin{array}{l}\text { Wall thickness/grubość } \\
\text { ścianek }\end{array}$ & {$[\mathrm{mm}]$} & 0.7 & 0.43 \\
\hline $\begin{array}{l}\text { Space velocity/prędkość } \\
\text { przeptywowa }\end{array}$ & {$\left[\mathrm{s}^{-1}\right]$} & 30.2 & 22.8 \\
\hline Regeneration/regeneracja & & FBC passive & FBC active \\
\hline $\begin{array}{l}\text { Manufacturer of } \mathrm{FBC} / \\
\text { producent }\end{array}$ & & Innospec & Pirelli Eco Technology \\
\hline Specification/specyfikacja & & Satacen ${ }^{\circledR} 4$ & CAM-FBC active \\
\hline $\begin{array}{l}\text { FBC content max./ } \\
\text { zawartość } F B C\end{array}$ & & $\begin{array}{c}20 \mathrm{mg} \mathrm{Fe} / \mathrm{kg} \text { fuel/ } \\
\mathrm{kg} \text { paliwa }\end{array}$ & $\begin{array}{c}20 \mathrm{mg} \mathrm{Fe} / \mathrm{kg} \text { fuel/ } \\
\mathrm{kg} \text { paliwa }\end{array}$ \\
\hline
\end{tabular}


ture of $300{ }^{\circ} \mathrm{C}$ and diluting approx. 1:100 (PMP compliant [10]). Thus only solid particles entered the instrumentation. The size classification is in very narrow bands, between 10 $-500 \mathrm{~nm}$ in 60 size classes. The defined particle size corresponds to the particle mobility diameter and is therefore representative for diffusion processes. This classification corresponds to deposition in the human respiratory system and penetration through the alveolar membrane [13]. The particle number concentration is quantified in a condensation core counter using the individual counting mode. The SMPS instrumentation from TSI with DMA 3081 and CPC 3772 were used.

\subsection{Thermogravimetric analysis (TGA)}

Soot was sampled at an average temperature of $320^{\circ} \mathrm{C}$, diluted by the SmartSampler tunnel and thereby cooled to a temperature of $25-30{ }^{\circ} \mathrm{C}$ at which temperature it was deposited on a quartz fiber filter for the thermogravimetric analysis.

The thermo-gravimetric procedure is well known and documented [14]. This investigation used the STA 409 CD instrument from Netzsch and a quadrupole mass spectrometer Aëolos, also from Netzsch, Germany. The measurements were done in pure oxygen atmosphere at a heating rate of $20{ }^{\circ} \mathrm{C} / \mathrm{min}$. in the temperature range of $40{ }^{\circ} \mathrm{C}-800^{\circ} \mathrm{C}$. The mass spectrometer was used to detect online the emission of the following substances: $\mathrm{H}_{2} \mathrm{O}, \mathrm{CO}, \mathrm{CO}_{2}, \mathrm{SO}, \mathrm{SO}_{2}$.

\subsection{EC/OC analysis}

The separation of the intercepted soot (again sampled on a quartz fiber filter) in elemental carbon EC and organic carbon OC indicates the character of the soot. It is an essential metric of the combustibility. Pure elemental carbon requires substantially higher combustion temperatures than a mixture with high organic content. The analysis was done using both the classical Coulometry (according to the German Standard VDI 2465) and also the NIOSH method 5040 [15]. The distinction EC/OC is also important in this investigation because in occupational health the Diesel particle emissions are usually evaluated according to its EC content [16].

\section{Results}

\subsection{Results of the engine tests}

Comparison at steady-state point $1400 \mathrm{rpm}$ and $340 \mathrm{~N} \cdot \mathrm{m}$

At this medium load point, the engine is measured with respect to all limited emissions and thermodynamic data as usual. The main results are summarized in Table 3. (zgodnie z zaleceniami PMP) [10]. Z tego względu w badaniach była brana pod uwagę tylko faza nierozpuszczalna. Pomiar wielkości odbywał się w wąskim zakresie między $10-500 \mathrm{~nm}, \mathrm{z}$ podziałem na 60 przedziałów klas wielkości. Zdefiniowana wielkość cząstek odpowiada wielkości mobilnych cząstek poruszających się w powietrzu. Zastosowana klasyfikacja jest dobrana do wielkości cząstek osadzających się w układzie oddechowym człowieka i przenikających przez błony pęcherzyków płucnych [13]. Liczba cząstek stałych została określona za pomocą urządzenia SMPS firmy TSI z DMA 3081 i CPC 3772.

\subsection{Analiza termograwimetryczna (TGA)}

Próbka sadzy była pobierana w temperaturze $320^{\circ} \mathrm{C}$ i rozcieńczana w Smart Samplerze, co spowodowało jej schłodzenie do temperatury $25-30^{\circ} \mathrm{C}$. Dzięki temu sadza osadzała się na filtrze z włókna kwarcowego i w ten sposób przygotowana została do analizy termograwimetrycznej. Metoda ta jest znana i była już opisywana w pracy [14]. Do badań wykorzystano system STA 409 CD oraz spektrometr masowy Aeolos niemieckiej firmy Netzsch. Pomiary wykonano w atmosferze czystego tlenu, a szybkość podgrzewania wynosiła $20^{\circ} \mathrm{C} / \mathrm{min}$ w zakresie temperatur $40-800{ }^{\circ} \mathrm{C}$. Spektrometr masowy był używany do pomiaru następujących związków: $\mathrm{H}_{2} \mathrm{O}, \mathrm{CO}, \mathrm{CO}_{2}, \mathrm{SO}$ i $\mathrm{SO}_{2}$.

\subsection{Analiza EC/OC}

Wydzielenie z sadzy (zebranej na filtrze z włókna kwarcowego) EC i OC umożliwia określenie jej właściwości możliwe jest wyznaczenie miary jej palności. Czysty węgiel wymaga znacznie wyższej temperatury spalania niż jego mieszanina z dużą zawartością składników organicznych. Analiza została przeprowadzona przy użyciu klasycznej kulometrii (zgodnie z niemiecką normą VDI 2465), a także metody NIOSH 5040 [15]. W przeprowadzonych badaniach ważne było również rozróżnienie EC/OC, ponieważ w aspekcie oddziaływania na zdrowie człowieka cząstki stałe są zwykle oceniane w zależności od zawartości EC [16].

\section{Wyniki badań}

\subsection{Wyniki badań silnikowych}

Porównanie wyników badań dla punktu pracy silnika 1400 obr/min i $340 \mathrm{~N} \cdot \mathrm{m}$

Dla tego punktu obciążenia silnika zmierzono emisję związków toksycznych i parametry termodynamiczne; wyniki tych pomiarów zamieszczono w tabeli 3 .

Najpierw dokonano pomiaru emisji gazów wylotowych w warunkach ustalonych z pominięciem cząstek stałych. $\mathrm{Na}$

Table 3. Limited emissions $\mathrm{CO}, \mathrm{HC}, \mathrm{NO}_{\mathrm{x}}$ and fuel consumption steady state. $\mathrm{PM}$ in the loading cycle

Tabela 3. Wyniki badań emisji związków toksycznych spalin, CO, HC, NO $i$ zużycie paliwa uzyskane w badaniach stacjonarnych

\begin{tabular}{|c|c|c|c|c|c|}
\hline Fuel/rodzaj paliwa & $\mathrm{CO}$ & $\mathrm{HC}$ & $\mathrm{NO}_{\mathrm{x}}$ & $\begin{array}{c}\text { Fuel consumption/ } \\
\text { zużycie paliwa }\end{array}$ & PM \\
\hline & {$[\mathrm{g} / \mathrm{kWh}]$} & {$[\mathrm{g} / \mathrm{kWh}]$} & {$[\mathrm{g} / \mathrm{kWh}]$} & 227.4 & {$[\mathrm{~kW}]$} \\
\hline ULSD & 0.62 & 0.25 & 6.79 & 7.49 & 227.9 \\
\hline HSD & 0.69 & 0.24 & 6.82 & 2.17 \\
\hline ULSD + FBC & 0.65 & 0.26 & 7.28 & 2.6 \\
\hline HSD + FBC & 0.65 & 0.26 & 229.0 \\
\hline
\end{tabular}


With the exception of PM, the emissions are measured at steady state as legally prescribed. The data are reported, as usual, energy specific in $[\mathrm{g} / \mathrm{kWh}$ ] terms. PM $[\mathrm{g} / \mathrm{kWh}]$ could not be determined in these tests, because particle samples had to be collected for subsequent TGA- and EC/OC-analysis. The reported PM [g/filter] data correspond to the loading cycle (as described in Fig. 4). There is no significant disparity in the Table 3 gaseous emissions and in the fuel consumption. The particle mass PM is higher for the tests with iron additive, as expected.

Particle size analysis in the raw gas (without DPF)

Figures 2 and 3 summarize size analysis with all 4 fuels at the operating point at $1400 \mathrm{rpm}$ and $340 \mathrm{~N} \cdot \mathrm{m}$.

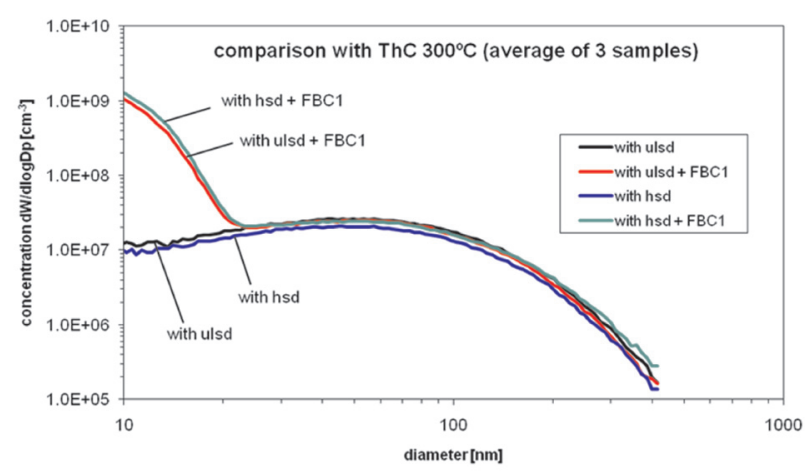

Fig. 2. Size distribution comparing the 4 fuel variants with gas sample pre-heating to $300^{\circ} \mathrm{C}$, as per PMP [10]

Rys. 2. Rozklad wielkości cząstek stałych dla 4 badanych paliw, próbka spalin podgrzewana do $300^{\circ} \mathrm{C}$ zgodnie z PMP [10]

The size distribution reveals almost no difference for the 4 fuel variants. The iron additive causes the expected increase of particle count in the range $10-25 \mathrm{~nm}$. These are ultra fine iron oxide clusters formed after combustion of the metal organic additive substances. These very fine particles result in a large specific surface that promotes catalytic effects during the filter regeneration. VERT certified DPF systems very efficiently intercept these fine FBC oxide particles as they remove all solid particles including metal oxide particles from engine wear and lubrication oil by over $99 \%$ to an extent that they are usually not detectable in the size spectrum after the DPF [8]. The filtration attributes of these two VERT-certified DPF are well documented. Hence, size measurements were not done after the DPF.

The measurements were repeated with sample heating to only $100{ }^{\circ} \mathrm{C}$.

This investigation was done to observe the condensate formation. $100{ }^{\circ} \mathrm{C}$ is far below the condensation point of sulfuric acid vapors. Sulfur contained in exhaust-gas, at temperatures below $300{ }^{\circ} \mathrm{C}$, usually generates a distinct bimodal size distribution with exceptionally high peaks. This investigation surprisingly found no condensate in the cool sample. With Pt-catalysis, sulfates would be formed according to the processes: $\mathrm{SO}_{2}+1 / 2 \mathrm{O}_{2} \rightarrow \mathrm{SO}_{3}$ and with the water present in the exhaust: $\mathrm{SO}_{2}+8 \mathrm{H}_{2} \mathrm{O}+1 / 2 \mathrm{O}_{2} \rightarrow$ $\mathrm{H}_{2} \mathrm{SO}_{4}+7 \mathrm{H}_{2} \mathrm{O}$, which explains the high contribution to PM podstawie otrzymanych pomiarów wyznaczano emisję jednostkową wyrażoną $\mathrm{w} \mathrm{g} / \mathrm{kWh}$. Następnie pobrano próbki do analizy TGA i EC/OC. Badania cząstek stałych wykonano w teście charakteryzującym się zmienną prędkością obrotową silnika i obciążeniem. Z zaprezentowanych w tabeli 3 danych wynika, że nie ma istotnych różnic w uzyskanych wynikach badań. Zgodnie z oczekiwaniami uzyskano większą emisję dla paliwa $z$ dodatkiem żelaza.

Analiza wielkości cząstek stałych w surowych spalinach (bez DPF)

Rysunki 2 i 3 zawierają podsumowanie analizy wielkości cząstek dla 4 paliw i punktu pracy silnika $1400 \mathrm{obr} / \mathrm{min} \mathrm{i}$ $340 \mathrm{~N} \cdot \mathrm{m}$. W czterech przebadanych wariantach paliwa nie

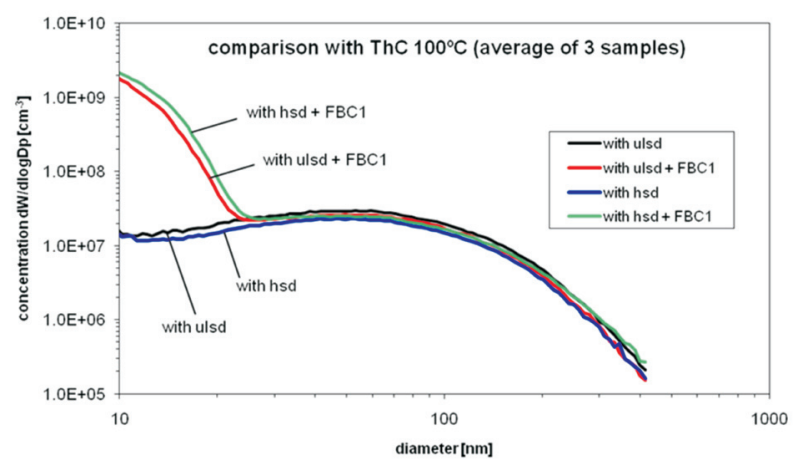

Fig. 3. Size distribution comparing the 4 fuel variants with the gas sample pre-heated to only $100^{\circ} \mathrm{C}$ in order to provoke sulfuric condensates Rys. 3. Rozklad wielkości cząstek stałych dla 4 badanych paliw, próbka spalin podgrzewana do $100^{\circ} \mathrm{C}$ w celu wymuszenia kondensacji siarczanów

odnotowano istotnych różnic w pomiarze wielkości cząstek stałych. Dodatek żelaza powoduje spodziewany wzrost ich liczby w zakresie $10-25 \mathrm{~nm}$. W przedziale tym występują bardzo małe aglomeraty tlenków żelaza, które powstają po spaleniu dodatku organicznego zawierającego metal. Te cząstki mają dużą powierzchnię, co jest korzystne dla procesu katalitycznego podczas regeneracji filtra. Certyfikowane przez VERT systemy DPF z dużą skutecznością przechwytują zarówno małe cząstki, jak i cząstki zawierające tlenki metali pochodzące ze zużycia silnika i oleju smarującego. Skuteczność ich działania wynosi ponad 99\%, dzięki czemu za DPF nie są wykrywane żadne zanieczyszczenia stałe [8]. Parametry filtracji tych dwóch systemów mających certyfikat VERT są zbadane i opisane, przez to pomiary wielkości cząstek za DPF nie były wykonywane.

Badania powtórzono dla próbki spalin podgrzanej do temperatury $100{ }^{\circ} \mathrm{C}$. Badanie wykonano w celu analizy formowania kondensatu. Temperatura $100^{\circ} \mathrm{C}$ jest znacznie mniejsza od temperatury punktu kondensacji par kwasu siarkowego. Siarka w spalinach w temperaturze poniżej $300^{\circ} \mathrm{C}$ zazwyczaj generuje odrębny bimodalny rozkład z wyjątkowo dużymi ,pikami”. W wynikach przeprowadzonych pomiarów nie stwierdzono kondensatu w chłodnych spalinach. W efekcie katalizy Pt siarczany zostały utworzone w procesie: $\mathrm{SO}_{2}+1 / 2 \mathrm{O}_{2} \rightarrow \mathrm{SO}_{3} \mathrm{i}$ w obecności wody w spalinach: $\mathrm{SO}_{2}+$ 
mass. Apparently the exhaust-gas did not contain $\mathrm{SO}_{3}$ and hence sulfuric acid was not formed. The sulfur in the fuel was obviously completely converted to $\mathrm{SO}_{2}$ and passed the system as gas, without forming sulfates.

Filter loading and regeneration

The filters became soot-loaded in a dynamic cycle as illustrated in Figure 4. Soot was generated in rapid acceleration cycles from idling until full load, thus avoiding the temperature rising to values at which the $\mathrm{FBC}$ doped fuel would trigger filter regeneration. The aim was to attain the highest possible filter loading to subsequently test the regeneration response.

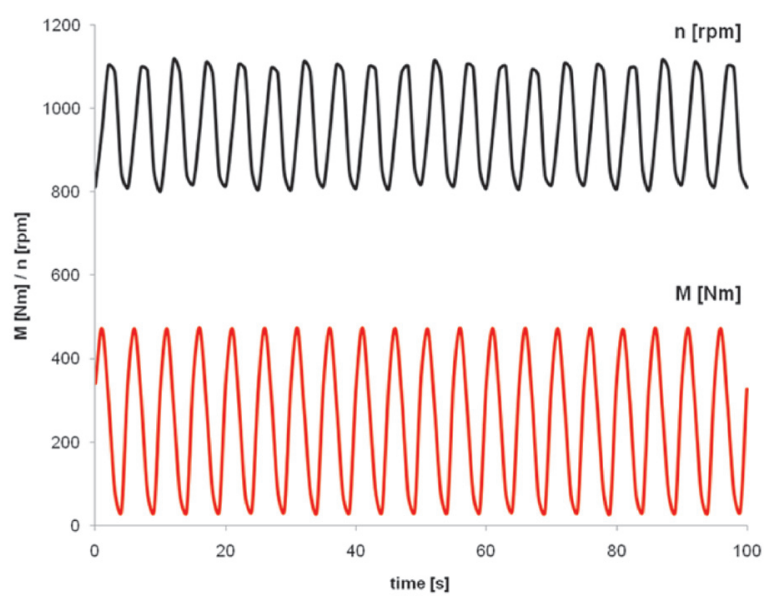

Fig. 4. Filter loading cycle

Rys. 4. Przebieg testu podczas zapetniania filtra

The exhaust backpressure rise, during filter loading, was not uniform for all fuels. This can be explained as follows: the test started with a new filter, which after regeneration still had some residual soot load. The second loading cycle thus has a distinctly different character and cannot be compared with the first. This will be further investigated at a later stage of this investigation.

Regeneration response

The filter loaded with soot in the described cycle, was regenerated according to the Swiss standard test protocol SN 277206 [17]. This test was only performed for the two FBC doped fuels. The results are shown in Fig. 5 and Fig. 6.

The regeneration begins below $340{ }^{\circ} \mathrm{C}$ exhaust-gas temperature. The load is increased every 20 minutes until full load. Plotted are the temperatures T7 before DPF and T8 after DPF, torque, pressure loss across the filter $\Delta \mathrm{p} 7$ and the particle emission in the CPC count.

The results (for two different DPF, two different additives but both iron-based and both 20 ppm dosage) show that, already at the first operating point, the back-pressure decreased despite increasing soot load and increasing volume throughput. Already at this $340{ }^{\circ} \mathrm{C}$ temperature, the balance-point is passed. Increasing the temperature steepens the regeneration gradient until termination of the test after running 20 minutes at full load. The regeneration is obviously
$8 \mathrm{H}_{2} \mathrm{O}+1 / 2 \mathrm{O}_{2} \rightarrow \mathrm{H}_{2} \mathrm{SO}_{4}+7 \mathrm{H}_{2} \mathrm{O}$, co tłumaczy ich duży udział w masie PM. Pozornie spaliny nie zawierają $\mathrm{SO}_{3}$, a więc nie powstał kwas siarkowy. Siarka z paliwa była całkowicie przekształcona w $\mathrm{SO}_{2}$ i została przetransportowana do układu jako gaz, bez formowania siarczanów.

Zapełnianie filtra $\mathrm{i}$ jego regeneracja

Nagromadzenie sadzy w filtrach odbywało się w teście dynamicznym przedstawionym na rysunku 4. Sadza została wygenerowana w wyniku zmian obciążenia i prędkości obrotowej od biegu jałowego do pełnego obciążenia. Pozwoliło to uniknąć wzrostu temperatury, dla której dodatek FBC do paliwa mógł spowodować regenerację filtra. Celem testu było uzyskanie możliwie największego zapełnienia filtra, aby później można było zbadać proces regeneracji filtra.

Wzrost przeciwciśnienia spalin podczas obciążania filtra nie był jednakowy dla wszystkich badanych paliw. Może to wynikać z tego, że badania rozpoczęto dla nowego filtra i po regeneracji pewna ilość sadzy pozostała w nim - ponowne zapełnianie filtra miało już inny charakter. Problem ten będzie przedmiotem kolejnych badań.

Regeneracja filtra

Regeneracja filtra odbywała się zgodnie ze szwajcarską procedurą SN 277206 [17]. Test ten był wykonywany tylko dla dwóch dodatków FBC. Wyniki przedstawiono na rysunkach 5 i 6 .

Regeneracja filtra zaczynała się dla temperatury spalin poniżej $340{ }^{\circ} \mathrm{C}$. Obciążenie zwiększano co 20 minut do wartości maksymalnej. Podczas badań rejestrowano: zmiany temperatur T7 przed DPF i T8 za DPF, moment obrotowy, spadek ciśnienia w filtrze $\Delta \mathrm{p} 7 \mathrm{i}$ emisję cząstek wyznaczoną za pomocą CPC.

Na podstawie uzyskanych wyników badań (dla dwóch różnych filtrów DPF, dwóch różnych dodatków - obu na bazie żelaza i obu w stężeniu 20 ppm) stwierdzono, że już w pierwszym punkcie pracy silnika przeciwciśnienie zmniejszyło się mimo zwiększenia ilości sadzy. Dla temperatury $340{ }^{\circ} \mathrm{C}$ przekroczono punkt równowagi (przecięcie linii na wykresach). Zwiększenie temperatury wywołało nagłe zwiększenie nachylenia linii reprezentującej regenerację, do zakończenia testu po 20 minutach pełnego obciążenia. Regeneracja oczywiście nie była jeszcze zakończona, co jest widoczne na wykresie. Tak więc następny test rozpoczynał się dla innych warunków początkowych. Mimo tej niedoskonałości procedury badawczej nie zaobserwowano znaczących różnic dla dwóch różnych paliw.

Różnica dwóch wykresów CPC jest zastanawiająca: dla filtra Dinex wartości są w zakresie 102 cząstek na cc, natomiast dla filtra Pirelli w zakresie 105. Wyniki te powinny być porównane z wynikami dla surowych spalin (rys. 2), które są w zakresie 107. To znaczy, że gdy dla filtra Dinex uzyskano skuteczność filtracji >99,99\% w tym teście, to dla filtra Pirelli skuteczność ta wynosi "tylko" 99\%. Różnica ta może wynikać z wielkości porów i grubości ścianek, a także z nieco innej grubości warstwy sadzy. Należy podkreślić, że certyfikat VERT filtrów gwarantuje filtracje najdrobniejszych cząstek stałych do poziomu $>99 \%$, nawet podczas regeneracji. 


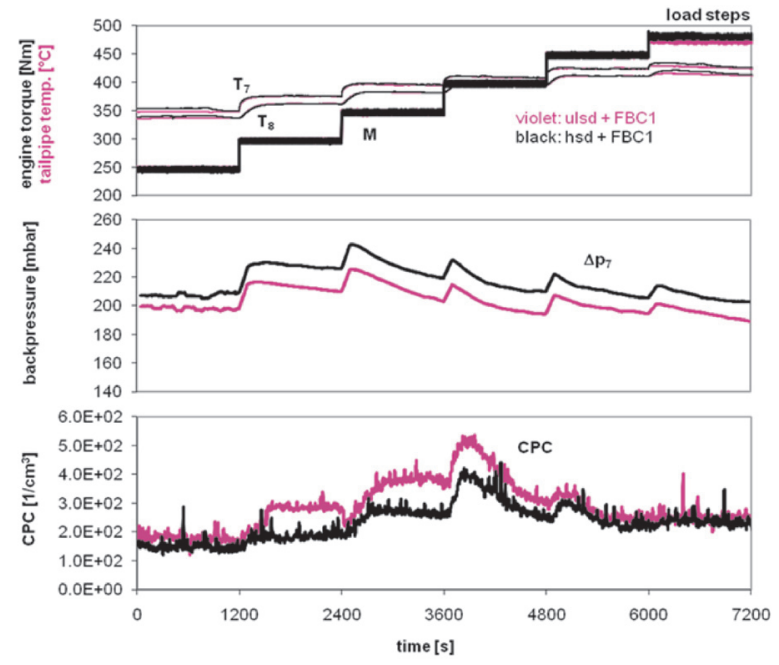

Fig. 5. Regeneration of the Dinex filter. ULSD and HSD, both with FBC Rys. 5. Przebieg regeneracji filtra Dinex dla silnika zasilanego paliwami: ULSD i HSD, oba z FBC

not yet complete, as evident in the gradients. Hence, the next test starts with slightly different initial conditions. Despite this imperfection of the test procedure, there is almost no evident difference between the two fuels.

The difference of the two CPC plots seems somehow striking: whereas the Dinex is in the range of 102 particles per cc, Pirelli is in the range of 105 . This should be compared to the raw emission (see Fig. 2) which is in the range of 107. In other words: while Dinex shows filtration efficiencies of $>99.99 \%$ in this test the Pirelli filter "only" shows $99 \%$. The difference in pore size and wall thickness may contribute to this difference but also slightly different soot layer thickness could explain most of it. It should be emphasized here that these VERT-certified filters keep filtration of solid ultrafine particles to a level of $>99 \%$ even during regeneration.

\subsection{Thermogravimetric analysis}

The entire investigation comprised four fuel variants. Figure 7 with thermo-gravimetric data, coupled with simultaneous MS-detection of volatile combustion products $\left(\mathrm{H}_{2} \mathrm{O}\right.$, $\mathrm{CO}, \mathrm{CO}_{2}, \mathrm{SO}, \mathrm{SO}_{2}$ ) only compares ULSD to HSD, both with FBC. The grey line pertains to data for ULSD. The black line pertains to data for HSD, which is the test fuel having

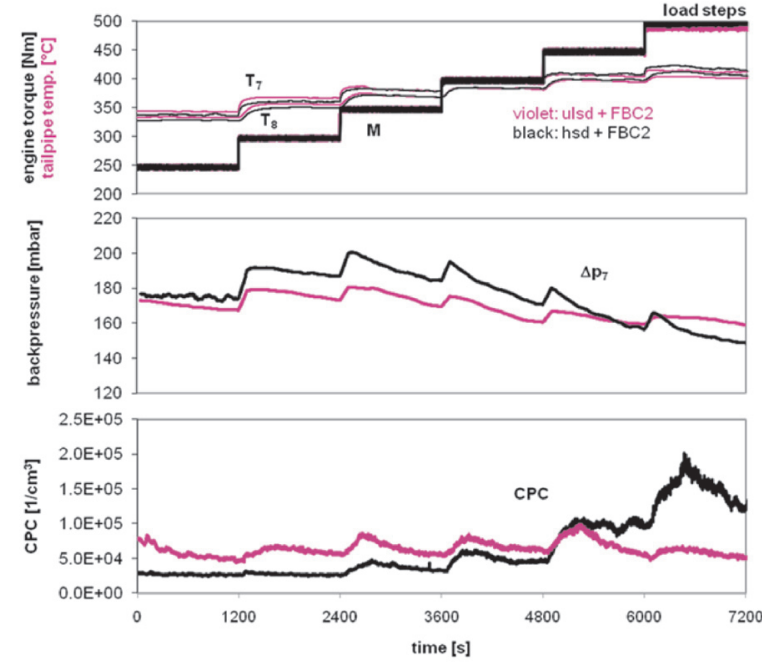

Fig. 6. Regeneration of the Pirelli filter. ULSD and HSD, both with FBC Rys. 6. Przebieg regeneracji filtra Pirelli dla silnika zasilanego paliwami: ULSD i HSD, oba z FBC

\subsection{Analiza termograwimetryczna}

Badania obejmowały cztery różne warianty paliwa. $\mathrm{Na}$ rysunku 7 przedstawiono dane $\mathrm{z}$ analizy termograwimetrycznej oraz wyniki pomiarów lotnych produktów spalania $\left(\mathrm{H}_{2} \mathrm{O}, \mathrm{CO}, \mathrm{CO}_{2}, \mathrm{SO}, \mathrm{SO}_{2}\right)$. Zestawienie dotyczy tylko dwóch paliw ULSD (szara linia) i HSD (czarna linia), oba z FBC. $\mathrm{W}$ funkcji zmian temperatury przedstawiano następujące dane: zmiany masy, prąd jonowy, parę wodną, $\mathrm{CO}, \mathrm{CO}_{2}$, $\mathrm{SO}, \mathrm{SO}_{2}$.

Rejestrowane prądy jonowe analizowanych związków lotnych są proporcjonalne do rozkładu objętości produktów w spalinach TG. Na rysunku 7 przedstawiono rozkład związków siarki dla pomiarów wykonanych z dużą rozdzielczością.

Otrzymane wyniki są podobne dla paliw o dużej i małej zawartości siarki. Podobieństwo to dotyczy pary wodnej w spalinach oraz początkowej fazy wysuszania w temperaturze powyżej $100^{\circ} \mathrm{C}$. O zapoczątkowaniu wypalania sadzy świadczy także zwiększenie ilości $\mathrm{CO}$ i $\mathrm{CO}_{2}$ w spalinach. Interesujące są zmiany zawartości $\mathrm{SO}$ i $\mathrm{SO}_{2}$. Emisja tych związków jest wyjątkowo mała w całym zakresie temperatur, także podczas wypalania sadzy. Należy zauważyć, że spala-
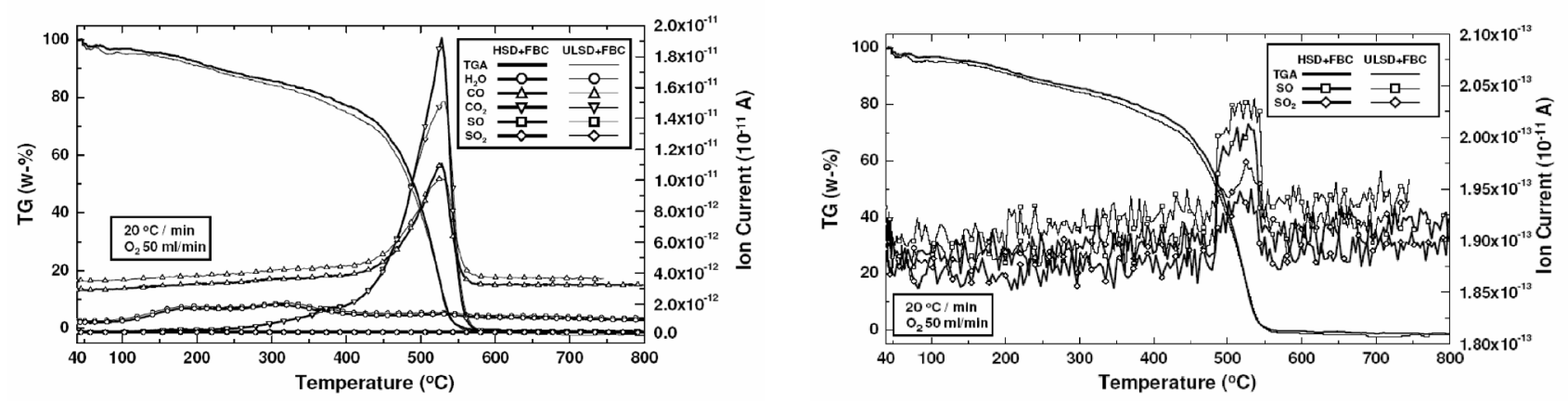

Fig. 7. Comparison of the TG-MS data recorded for ULSD and HSD; both with 20 ppm iron additive Rys. 7. Porównanie sygnału TG-MS dla paliw ULSD i HSD, oba z dodatkiem żelaza 20 ppm 
high sulfur content. Charted as a function of the increasing temperature are: mass loss and ion current, water vapor, $\mathrm{CO}$, $\mathrm{CO}_{2}, \mathrm{SO}, \mathrm{SO}_{2}$.

Ion-currents recorded for the observed volatile decomposition products are proportional to the volume portion of the decomposition product in the TG exhaust. The lower figure shows the sulfur decomposition products at a higher resolution.

The response is surprisingly similar for the low-sulfur and the high-sulfur fuel. The similarity prevails for the emission of water vapor and the first drying phase, at temperatures above $100{ }^{\circ} \mathrm{C}$, and also for the initiation of soot combustion evidenced by spikes of $\mathrm{CO}$ and $\mathrm{CO}_{2}$. Very remarkable is the response of gaseous sulfur emissions $\mathrm{SO}$ and $\mathrm{SO}_{2}$. These emissions are exceptionally low, in the entire temperature range, including the gradual increase during soot combustion. Noteworthy is that combustion of the high sulfur fuel soot does not produce more $\mathrm{SO}$ and $\mathrm{SO}_{2}$ emissions. This investigation thus confirms that the high sulfur content does not proportionally deposit on the soot, but obviously exits the system as gaseous $\mathrm{SO}_{2}$.

Figure 8 is another interesting comparison. It shows the thermo-gravimetric analysis for the effects of the fuel additive on the regeneration.

Evidently, the FBC triggers the start of regeneration at about $340{ }^{\circ} \mathrm{C}$, which is $160 \mathrm{~K}$ below the temperature the soot is starting to burn without FBC support and thereby enables faster and more complete filter regeneration, which however, is not visible in this diagram.

\section{3. $\mathrm{EC} / \mathrm{OC}$}

During filter loading, samples are collected on quartz filters. These samples are analyzed using the Coulometry procedure VDI 2465 as well as the NIOSH procedure [15]. Table 4 summarizes the results.

The data listed for OC and EC are the absolute mass per filter sample. This mass naturally differs from case to case. These absolute values are therefore not mutually comparable. Instead, the ratio of elemental carbon EC to total carbon $\mathrm{TC}=\mathrm{EC}+\mathrm{OC}$ is compared for both measurement procedures. Despite the inevitable measurement variability, the results are very uniform. Hence, there is no identifiable disparity between the fuel variants. The HSD data tends to a slightly lower EC/TC ratio, but the differences are rather nie sadzy z silnika zasilanego paliwem o dużej zawartości

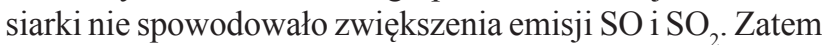
wykonane badania potwierdzają, że duża zawartość siarki nie powoduje proporcjonalnego jej osadzania na sadzy, ale jest emitowana jako gazowe $\mathrm{SO}_{2}$.

Na rysunku 8 przedstawiono porównanie dotyczące termograwimetrycznej regeneracji dla dodatków paliwowych. $\mathrm{Z}$ analizy rysunku wynika, że FBC powoduje rozpoczęcie regeneracji przy temperaturze około $340{ }^{\circ} \mathrm{C}$, czyli $160 \mathrm{~K}$ poniżej temperatury zapłonu sadzy. Dzięki temu możliwa jest szybsza i pełniejsza regeneracji filtra.

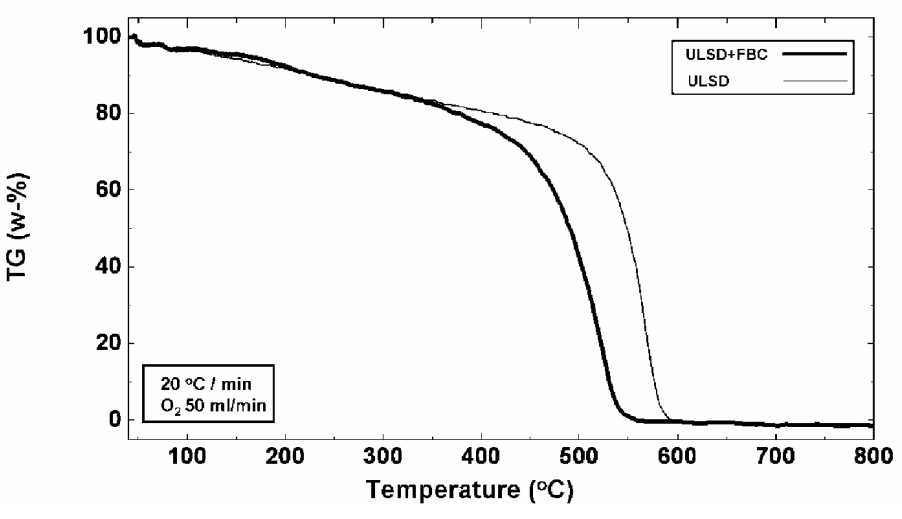

Fig. 8. TGA analysis for the ULSD fuel with and without iron FBC Rys. 8. Analiza TGA dla paliwa ULSD z i bez FBC na bazie żelaza

\section{3. $\mathrm{EC} / \mathrm{OC}$}

Podczas napełniania filtra próbki są pobierane na filtrze kwarcowym. Analiza dokonywana jest przy użyciu kulometrii, zgodnie z procedurą VDI 2465 oraz NIOSH [15]. Zestawienie wyników przedstawiono w tabeli 4.

Zestawione dane dla OC i EC odnoszą się do mas całkowitych próbek na filtrze. Ponieważ masy te są różne dla każdego z przebadanych wariantów, nie można ich porównywać bezwzględnie. Zamiast tego porównano stosunek części EC węgla do całkowitego węgla $\mathrm{TC}=\mathrm{EC}+\mathrm{OC}$ dla obu procedur pomiarowych. Mimo nieuniknionych rozrzutów pomiarów, wyniki są bardzo podobne. Utrudnia to jednoznaczne określenie różnic dla badanych paliw. Wydaje się, że paliwo HSC ma nieco mniejszy stosunek EC/TC, jednak otrzymane różnice są nieduże.

Table 4. EC/OC analysis of soot samples from filter loading test

Tabela 4. Analiza EC/OC próbki sadzy pobranej z filtra

\begin{tabular}{|l|c|c|c|}
\hline \multirow{2}{*}[\mu\mathrm{g}/\text{filter}]{} & \multicolumn{3}{|c|}{ Coulometry VDI 2465/kulometria } \\
\cline { 2 - 4 } & OC & EC & EC/TC \\
\hline ULSD & 212 & 1838 & $89.7 \%$ \\
\hline HSD & 236 & 1750 & $88.1 \%$ \\
\hline ULSD + FBC & 307 & 2193 & $87.7 \%$ \\
\hline HSD + FBC & 279 & 1893 & $87.1 \%$ \\
\hline Blind value & 44 & 26 & - \\
\hline
\end{tabular}

\begin{tabular}{|c|c|c|c|}
\hline \multirow{2}{*}[\mu\mathrm{g}/\text{filter}]{} & \multicolumn{3}{|c|}{ NIOSH 5040} \\
\cline { 2 - 4 } & OC & EC & EC/TC \\
\hline ULSD & 205 & 1905 & $90.3 \%$ \\
\hline HSD & 238 & 1849 & $88.6 \%$ \\
\hline ULSD + FBC & 409 & 2157 & $84.1 \%$ \\
\hline HSD + FBC & 317 & 1882 & $82.5 \%$ \\
\hline Blind value & 50 & 4 & - \\
\hline
\end{tabular}


insignificant.

\section{Conclusion}

This investigation compared 2 DPF-systems using iron based FBC-regeneration with European Diesel fuel (sulfur content $<10 \mathrm{ppm}$ ) and high sulfur test fuel (sulfur content 1369 ppm) as it is typically used in China. No significant differences were found in the limited emissions $\mathrm{CO}, \mathrm{HC}, \mathrm{NO}_{x}$ and $\mathrm{PM}$, the $\mathrm{EC} / \mathrm{OC}$ ratio of the soot, in the characteristics of residual soot combustion (TGA) and the regeneration response. Evidently, the FBC iron-oxide enables that the sulfur (both in the fuel and in the lube oil) entering combustion subsequently exits as gaseous $\mathrm{SO}_{2}$. No sulfate is formed and thus the particle formation is unaffected. In contrast to this: whereas when a-thus sulfate is formed, which increases the particle mass and inhibits filter regeneration. Consequently, precious metal DOC and Pt-coated DPF are unsuitable for HSD fuels. But particle filter systems without catalytic attributes, or with base metal catalysts, can perfectly cope with very high sulfur fuel content. The soot particles are efficiently filtered, without undesirable side-effects, and the filters are effectively regenerated. This ensures durable and dependable operation. These conclusions are of course limited to short term effects and to the operation profiles used during this investigation. Further investigations will be required.

\section{Acknowledgement}

This investigation was performed within the scope of a Sino-Swiss project. It studied the particle filter technology for off-road deployment in Chinese cities. The authors are grateful to the SDC (Swiss Agency for Development and Cooperation), VECC (Chinese Vehicle Emission Control Center), BJEPB ( Beijing Environment Protection Bureau), the filter manufacturers PIRELLI and DINEX and the VERT-network (Association of BAT Particle Filter producing companies) for helping to finance the tests and for the agreement to publish the results.

\section{Wnioski}

Zaprezentowane badania dotyczą porównania dwóch systemów DPF, wykorzystujących FBC na bazie żelaza, dla paliwa używanego w Europie (zawartość siarki wynosi $<10 \mathrm{ppm}$ ) i paliwa stosowanego w Chinach (zawartość siarki wynosi $1369 \mathrm{ppm})$. Na podstawie otrzymanych wyników badań nie stwierdzono istotnych różnic w emisji $\mathrm{CO}, \mathrm{HC}$, NOx i PM, wartości EC/OC sadzy oraz w pozostałościach po dopalaniu sadzy. Zastosowanie FBC na bazie żelaza powoduje, że siarka (zarówno z paliwa, jak i z oleju smarującego) jest emitowana w spalinach jako $\mathrm{SO}_{2}$. Ponadto nie formują się siarczany, co nie powoduje zmian w emisji cząstek stałych. Przy zastosowaniu katalizatora z metalu szlachetnego, przy użyciu paliwa o dużej zawartości siarki może zachodzić konwersja $\mathrm{SO}_{2}$ do $\mathrm{SO}_{3}[6,18,19]-\mathrm{w}$ ten sposób tworzy się siarczan, który zwiększa masę cząstek oraz utrudnia regenerację filtra. $Z$ tego względu DOC z katalizatorami z metali szlachetnych i DPF z powłoką Pt nie nadają się do zastosowania z paliwami o dużej zawartości siarki, natomiast dla paliw tych z powodzeniem mogą być stosowane filtry bez katalizatora lub z katalizatorami na bazie metali nieszlachetnych. Wtedy sadza jest skutecznie filtrowana, bez niepożądanych skutków ubocznych, a filtry są regenerowane z dużą skutecznością. Dzięki temu zapewnione jest długotrwałe i niezawodne działanie filtrów. Wnioski te sformułowano na podstawie krótkotrwałych pomiarów i z tego powodu wskazane jest prowadzenie dalszych prac badawczych.

Paper reviewed/Artykut recenzowany

\section{Acronyms and abbreviations/Skróty i oznaczenia}

AFHB University of Applied Sciences, Biel, Switzerland/Uniwersytet Nauk Stosowanych, Biel, Szwajcaria

BM Base Metal/metal nieszlachetny

CPC Condensation Particle Counter/kondensacyjny licznik czastek

CPSI Cells per square inch/liczba cel na cal kwadratowy

CRT Continuously Regenerating Trap (trademark Johnson Matthey)/filtr czastek z regeneracja ciagła (znak towarowy Johnson Matthey)

DC Diffusion Charger/tadowanie dyfuzyjne

DOC Diesel Oxidation Catalyst/utleniajacy reaktor katalityczny do silników ZS

DMA Differential Mobility Analyser/analizator różnicowy

DPF Diesel Particle Filter/filtr czastek statych

DPX Catalyst coated DPF (trademark Engelhard)/filtr cząstek statych $z$ warstwa katalityczna (znak towarowy Engelhard)
EC Elemental Carbon/węgiel pierwiastkowy

EGR Exhaust Gas Recirculation/recyrkulacja gazów spalinowych

EMPA Eidgenössische Material Forschungs und Prüfanstalt, Dübendorf, Switzerland/Laboratorium Badań Materiałowych, Dübendorf, Szwajcaria

EN, ISO, SN Standards: European Norm, International Standard, Swiss/Normy: europejskie, międzynarodowe, szwajcarskie

FBC Fuel Borne Catalyst/dodatek do paliwa obnizajacy temperaturę zapłonu $P M$

HSD High sulfur diesel/paliwo o dużej zawartości siarki do silników ZS

LD Light duty/lekkie silniki (pojazdy)

MS Mass spectrometry/spektrometria masowa

$\mathrm{nm} \quad$ Nanometer $=10^{-9} \mathrm{~m}$; vóvvos $($ greek $)=$ the dwarf $/$ nanometr 
NIOSHNational Institute for Occupational Safety and Health/ Narodowy Instytut Bezpieczeństwa i Higieny Pracy

NO Nitrogen monoxide/tlenek azotu

$\mathrm{NO}_{2} \quad$ Nitrogen dioxide/dwutlenek azotu

$\mathrm{OC}^{2}$ Organic carbon/węgiel organiczny

PAS Photoelectric Aerosol Sensor/fotoelektryczny czujnik rozpylenia

PGM Platinum Group Metals/metale z grupy platynowców

PM Particulate matter/czastka stata

PMP Particle Measurement Program/program dotyczacy pomiarów cząstek statych

ppm Parts per million/część na million

S Sulfur/siarka

$\mathrm{SO}, \mathrm{SO}_{2}$ Suflur oxides/tlenki siarki
SMPS Scanning Mobility Particle Sizer (Instruments TSI, USA)/ mobilny analizator do pomiaru wielkości cząstek (producent TSI Incorporated, USA)

TGA Thermogravimetric analysis/analiza termograwimetryczna

TC Total Carbon $=\mathrm{EC}+\mathrm{OC} /$ catkowita ilość węgla

ThC Thermo-Conditioning $=$ preheating of the gas sample line/ grzana linia pomiarowa

ULSD Ultra low Sulfur Diesel/paliwo o niskiej zawartości siarki

VDI Association of German Engineers/Niemieckie Stowarzyszenie Inżynierów

VEMC Vehicle Emission Management Center, Beijing/Centrum Zarzadzania ds. Emisji z Pojazdów, Pekin

VERT ${ }^{\circledR}$ Verification of Emission Reduction Technologies, a trade mark/potwierdzenie technologii zmniejszenia emisji, znak towarowy

\section{Bibligraphy/Literatura}

[1] Diesel Particulate Emission Control, SP-537; SAE International Congress, Detroit, Feb.28.1983.

[2] Mayer A.: Einfluss des Treibstoffs auf die Grössenverteilung ultrafeiner Partikel bei Dieselmotoren Technische Akademie Esslingen, 2nd Colloquium Fuels, 20./21.1.1999.

[3] Song.J et al.: Fuel Sulfur Effect on Membrane Coated Diesel Particulate Filter; SAE 2002-01-2788.

[4] Worldwide Fuel Charter, September 2006; www.autoalliance. org

[5] Euro 5/6 for emissions of light passenger and commercial vehicles: EC-Regulation No. 715/2007.

[6] Maricq M. et al.: The effects of the catalyst and fuel sulfur on PM-emissions. HEI Annual Conference 2009.

[7] Allansson R. et al.: The Use of the Continuously Regenerating Trap (CRTTM) to Control Particulate Emissions: Mini mizing the Impact of Sulfur Poisoning,, SAE 2002-01-1271.

[8] Mayer A. et al.: Retention of Fuel Borne Catalyst Particles by Diesel Particle Filter Systems, SAE 2003-01-0287.

[9] Mayer A. et al.: Particle Filter Properties after 2000 hrs Real World Operation, SAE 2008-01-0332.

[10] UN-ECE R83 annex 4 Appendix 5

[11] VERT® Filter List, October 2010, www.vert-certification.eu
[12] Kasper M.: The number concentration of non-volatile particles; SAE 2004-01-0960.

[13] Oberdörster G. et al.: Nanotoxicology, an Emerging Discipline Evolving from Studies of Ultrafine Particles. Environmental Health Perspective, July 2005

[14] Jaenicke-Rössler K., Leitner G.: TA-MS for high temperature materials. Thermochimica Acta 295 (1997) 133-145 (Elsevier).

[15] Birch M.E., Cary R.A.: Elemental Carbon-Based Method for Monitoring Occupational Exposures to Particulate Diesel exhaust, Aerosol Science and Tech., 68(3): 1996.

[16] Grenzwerte am Arbeitsplatz 2007, Suva, Schweizerische Unfallversicherungs-Anstalt, Nr. 1903.d www.suva.ch/waswo

[17] SN 277206, Testing of Particle Filter Systems for Internal Combustion Engines, www.bafu.admin.ch/partikelfilterliste

[18] Ken Friis Hansen et al.: DTI, Large-scale project with particulate filters on heavy-duty vehicles in Odense, June 2002, ISBN 87-90661-31-1.

[19] Bémer D., Depay J.P., Lauzier F.: Emission Diesel performances des filtres à particules pour engins non routiers, INRS Hygiène et sécurité du travail, 1er trimestre 2010.
Prof. Jan Czerwiński, DEng. - Laboratorium for IC-Engines and Exhaust Gas Control, University of Applied Sciences Biel-Bienne, Switzerland.

Prof. dr Jan Czerwiński - Laboratorium Silników Spalinowych i Emisji Spalin, Uniwersytet Nauk Stosowanych w Biel-Bienne, Szwajcaria. e-mail: jan.czerwinski@bfh.ch

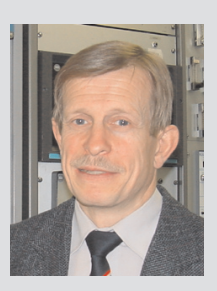

Peter Bonsack, MEng. - research assistant at the Center for Alternative Fuels, Engines and Emissions at West Virginia University, USA.

Inż. Peter Bonsack-asystent badawczy w Centrum badawczym paliw alternatywnych, silników i emisji na Uniwersytecie West Virginia, USA.

e-mail: peter.bonsack@mail.wvu.edu

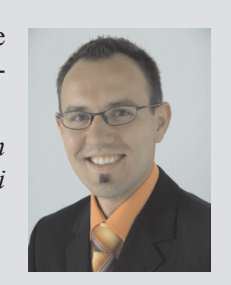

Andreas Mayer, MEng. - Technik Thermische Maschinen (TTM), Switzerland.

Inż. Andreas Mayer - pracownik Termodynamicznej Techniki Maszyn (TTM), Szwajcaria.

e-mail: ttm.a.mayer@bluewin.ch

Lassi Karvonen, DSc. - scientist at Empa - Swiss Federal Laboratories for Materials Science and Technology, Swiss.

Dr Lassi Karvonen - pracownik naukowy w Empa - Szwajcarskim Federalnym Laboratorium Nauko Materiałach i Technologii, Szwajcaria.

e-mail: lassi.karvonen@empa.ch 